\title{
Performans Reproduksi Sapi Lokal yang Toleran Terhadap Iklim di Merauke
}

\section{Local Cattle Reproduction Performance Tolerans on The Climate in Merauke}

\author{
Nurcholis* dan S. M. Salamony \\ Jurusan Peternakan Fakultas Pertanian Universitas Musamus \\ *E-mail: nurcholis@unmus.ac.id \\ (Diterima: 28 November 2018; Disetujui: 22 Januari 2019)
}

\begin{abstract}
ABSTRAK
Potensi merauke sebagai daerah penghasil sapi potong di kawasan timur Indonesia telah di tetapkan oleh pemerintah, namun perlu adanya kajian lebih lanjut tentang kemampuan produksi dan reproduksi sapi lokal yang tolerans terhadap iklim di merauke. Tujuan dari penelitian ini adalah untuk mengetahui performas reproduksi sapi lokal di merauke, dewasa kelamin, umur pertama kawin, siklus birahi, lama estrus, lama kebuntingan, kawin kembali setelah beranak dan calving interval. Metode yang digunakan adalah survei secara langsung dan wawancara pada peternak. Data primer diperoleh dari dinas peternakan dan kesehatan hewan kabupaten merauke, sedangkan data sekunder di peroleh dari hasil wawancara dengan inseminator. Data diolah secara statistik menggunakan analisis deskriptif dalam bentuk rata-rata dan standar deviasi dari setiap peubah yang diamati. Pengambilan sampel dilakukan dengan cara purposive sampling menggunakan sapi sebanyak 90 ekor. Hasil analisis menunjukkan performans reproduksi pada sapi jantan (pubertas) 17,20 $\pm 0,066$ bulan, umur pubertas sapi betina 20.90 $\pm 0,099$ bulan, umur sapi dara pertama kali dikawinkan $24.50 \pm 0,008$ bulan. Lama bunting anak jantan $278,33 \pm 0,011$ hari, lama bunting

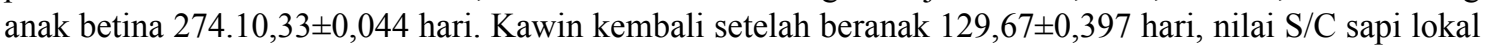
$>1$ namun dalam ambang batas normal dan tingkat kematian pedet mencapai 18,04\% yang diakibatkan oleh faktor eksternal. Kesimpulan penelitian ini adalah Performa reproduksi pada sapi lokal di merauke dengan keadaan suhu tinggi dalam keadaan normal.
\end{abstract}

Kata kunci: performans, reproduksi, sapi lokal

\begin{abstract}
Merauke's potential as a region producing beef cattle in eastern Indonesia has been determined by the government, but there must be further studies on the production and reproduction capabilities of local cattle that are tolerant to the climate in Merauke. The purpose of this study was to determine the reproductive performance of local cattle in Merauke, maturity sex, age at first mating, lust cycle, estrus dilemma, length of pregnancy, remarry after calving and calving interval. The method used is a direct survey and interviews with Breeders. Primary data was obtained from the livestock service and regency animal health department, while secondary data was obtained from interviews with inseminator. Data processed statistically using descriptive analysis in the form of averages and the standard deviation of each observed variable. Sampling was done by purposive sampling using as many as 90 cattle. The results showed reproductive performance in male cattle (puberty) $17.20 \pm 0.066$ months, age of puberty of female cattle $20.90 \pm 0.099$ months, the age of heifers first mated $24.50 \pm 0.008$ months. The length of pregnancy for a male was $278.33 \pm 0.011$ days, the length of pregnancy for a female was $274.10 .33 \pm 0.044$ days. Copulation after giving birth to $129.67 \pm 0.397$ days, the local $S / C$ value $>1$ but within the normal threshold and the calves mortality rate reached $18.04 \%$ due to external factors. The conclusion of this study is the reproductive performance in local cattle in Merauke with high-temperature conditions under normal conditions.
\end{abstract}

Keywords: local cattle, performance, reproduction 


\section{PENDAHULUAN}

Ternak sapi lokal yang mampu berkembangbiak di sekitar wilayah merauke adalah ternak sapi yang memiliki kemampuan beradaptasi dan tolerans terhadap iklim serta pakan di merauke. Suhu di kabupaten Merauke pada kondisi kemarau dan siang hari dapat mencapai $30^{\circ} \mathrm{C}-33^{\circ} \mathrm{C}$ dengan kelembapan mencapai 87\% (BMKG, 2018). Lingkungan yang tidak stabil seperti suhu yang tinggi dan pakan yang bernutrisi rendah dapat mengakibatkan cekaman sehingga meningkatkan stress pada ternak dan berdampak terhadap gangguan produksi hingga reproduksi ternak. Sapi -sapi yang mampu beradaptasi ini memiliki potensi genetik yang baik untuk dipertahankan dalam konteks peningkatan jumlah populasi ternak sapi di kawasan merauke. Ternak sapi di kawasan merauke ini sebagian besar dibudidayakan secara tradisional, sehingga pakan yang diberikan adalah rumput lapang di area padang pengembalaan dengan kandungan nutrisi protein kasar $9 \%$ atau jerami padi pada musim panas, sehingga produktivitas ternak menjadi rendah dan produksi daging semakin menurun.

Ketersediaan daging yang semakin menurun harus ditingkatkan dengan produktivitas ternak yang maksimal, untuk menjaga ketersediaan secara berkelanjutan, oleh sebab itu dasar utama dalam sistim budidaya khususnya reproduksi penting untuk diketahui oleh masyarakat diantaranya jumlah kelahiran anak sapi pertahun. Calving interval merupakan salah satu tolak ukur dalam melihat produktivitas ternak dan seharusnya konsisten agar produksi ternak tetap stabil. Hingga saat ini informasi terkait dengan calving interval hingga performans reproduksi sapi lokal di Merauke masih sangat sedikit, oleh sebab itu berdasarkan uraian di atas maka penelitian terkait dengan performans perlu dikaji lebih lanjut sehingga plasma nutfa sapi lokal di merauke dapat dikembangbiakan sesuai dengan kondisi lingkungan yang ada. Tujuan dari pada penelitian ini adalah untuk mengetahui performas reproduksi sapi lokal yaitu dewasa kelamin, umur pertama kawin, siklus birahi, lama estrus, lama kebuntingan, birahi kembali setelah beranak, kawin kembali setelah melahirkan dan calving interval.

\section{METODE}

Penelitian dilaksanakan di beberapa tempat diwilayah distrik semangga, tanah miring dan kurik dengan jumlah ternak mencapai 90 ekor sapi. Pemilihan lokasi tersebut berdasarkan jumlah populasi sapi terbanyak di setiap distrik yang berada di kabupaten Merauke. Penelitian ini dilaksanakan dengan metode survei langsung dan wawancara pada petani ternak. Data primer di antaranya jumlah IB dalam satu tahun, serta tingkat keberhasilan IB diperoleh dari Dinas Tanaman Pangan Peternakan dan Kesehatan Hewan Kabupaten Merauke, sedangkan data sekunder di peroleh dari hasil wawancara dengan peternak dan inseminator. Pengambilan sampel dilakukan dengan cara purposive sampling.

Peubah yang diukur diantaranya adalah sifat-sifat reproduksi ternak yaitu 1) umur pubertas, 2) umur sapi dara pertama kali dikawinkan, 3) lama siklus birahi, 4) lama bunting, 5) umur kawin kembali setelah beranak, 6) pertama kali pejantan mulai jadi pemacek, 7) kegagalan beranak, 8) persentase kematian setelah beranak.

Analisis data performans reproduksi yang diperoleh akan dianalisis deskriptif dalam bentuk rata-rata dan standar deviasi dari setiap peubah yang diamati.

\section{HASIL DAN PEMBAHASAN}

Hasil penelitian performans reproduksi pada sapi lokal pada Tabel 1 menunjukkan bahwa, performas reproduksi (pubertas) pada sapi jantan 17,20 $\pm 0,066$ bulan, umur pubertas sapi betina 20,900 $\pm 0,099$ bulan, umur sapi pertama kali dikawinkan $24.50 \pm 0,008$ bulan. Betina yang bunting dengan anak jenis 
Tabel 1. Performans Reproduksi Pada Sapi Lokal di Tiga Distrik

\begin{tabular}{|c|c|c|c|c|c|}
\hline \multirow{2}{*}{ Variabel } & \multicolumn{3}{|c|}{ Rataan Per Distrik } & \multirow{2}{*}{ Rataan } & \multirow{2}{*}{ SD } \\
\hline & $\mathrm{A}$ & $\mathrm{B}$ & $\mathrm{C}$ & & \\
\hline Umur pubertas Jantan (bulan) & 17,3 & 16,1 & 18,2 & 17,20 & 0,066 \\
\hline Umur Pubertas betina (bulan) & 22,2 & 20,2 & 20,3 & 20,90 & 0,099 \\
\hline $\begin{array}{l}\text { Persentase kematian pedet Setelah lahir } \\
\text { (ekor) }\end{array}$ & 8 & 2 & 4 & 4,67 & 1,510 \\
\hline $\mathrm{S} / \mathrm{C}$ & 1,8 & 1,6 & 2 & 1,8 & 0,100 \\
\hline CR & 60 & 80 & 60 & 67 & 0,333 \\
\hline $\begin{array}{l}\text { Umur sapi dara pertama kali dikawinkan } \\
\text { (bulan) }\end{array}$ & 24,2 & 24 & 25,3 & 24,50 & 0,008 \\
\hline Lama siklus birahi (hari) & 23 & 20 & 22 & 21,67 & 0,136 \\
\hline Lama bunting anak jantan (hari) & 278 & 275 & 282 & 278,33 & 0,011 \\
\hline Lama bunting anak betina (hari) & 276 & 275 & 272 & 274,33 & 0,004 \\
\hline Umur kawin kembali setelah beranak (hari) & 131 & 126 & 132 & 129,67 & 0,397 \\
\hline Kematian pedet (ekor) & 11 & 6 & 8 & 8,33 & 0,625 \\
\hline
\end{tabular}

Keteterangan: A (Semangga), B (Kurik), C (Tanah miring), SD (Standar Deviasi)

kelamin jantan rata-rata $278,33 \pm 0,011$ hari, Betina yang bunting dengan anak jenis kelamin betina $274,33 \pm 0,004$ hari. Kawin kembali setelah beranak $122 \pm 0,016$ hari.

Umur pubertas sapi lokal jantan dan betina pada ketiga distrik di Kabupaten Merauke dapat dilihat bahwa paling rendah adalah distrik kurik yaitu 18,2 bulan dan 20,3 bulan, namun antara ketiganya hampir memiliki kesamaan dalam waktu pubertas pada sapi lokal, dapat dilihat bahwa umur pubertas pada sapi lokal betina lebih tinggi bila dibandingkan dengan sapi jantan. Hasil penelitian ini dalam batas normal dan sejalan dengan penemuan Novita et al. (2018) yang menyatakan bahwa sapi betina aceh memiliki umur pubertas rata- rata $12-24$ tahun. Menurut Tolihere (1987) bahwa umur pubertas pada sapi zebu keturunan adalah 12-30 bulan, dan Bahktiar (2015) melaporkan bahwa umur pubertas sapi bali rata-rata mencapai 16.80 bulan pada jantan dan 20,45 bulan pada betina. Perbedaan silkus estrus diduga dipengaruhi oleh iklim disuatu daerah seperti suhu yang tinggi dapat meningkatkan stress yang berdampak pada pengaruh hormon. Tingkat stres dapat mempengaruhi hormon estradiol sehingga siklus estrus menjadi fluktuatif (Sumiyohsi et al., 2014). Menurut Iskandar (2011) bahwa temperatur yang tinggi $\left(27^{\circ} \mathrm{C}-34^{\circ} \mathrm{C}\right)$ dapat memperlambat proses pubertas pada sapi. Suhu yang tinggi dapat berpengaruh terhadap tingkah laku makan, sehingga asupan nutrisi seperti protein dan energi pada tubuh menjadi lebih rendah yang berpengaruh terhadap status reproduksi yaitu pubertas sapi. Hal ini sejalan dengan pendapat Umiyasih dan Anggraeny (2007) menyatakan bahwa kekurangan energy dapat menghambat perkembangan seksual dan pubertas pada ternak.

Hasil penelitian menunjukkan bahwa dari 30 ekor sapi yang dilakukan inseminasi buatan (IB), nilai sevice per coception (S/C) 1,70 dan conception rate (CR) $73 \%$. Hal ini dapat diartikan bahwa $\mathrm{S} / \mathrm{C}$ pada setiap satu ekor sapi betina membutuhkan rata-rata lebih dari satu kali insemiansi untuk sapi betina menjadi bunting. Namun hasil S/C ini dalam kisaran normal menurut Ihsan dan wahyuningsih (2011) bahwa S/C normal berkisar diantara 1,5-2. Faktor - faktor yang menyebabkan terjadinya masalah $\mathrm{S} / \mathrm{C}>1$ diduga adalah kemampuan SDM inseminator, 
Vol. 21 (1): 27-33

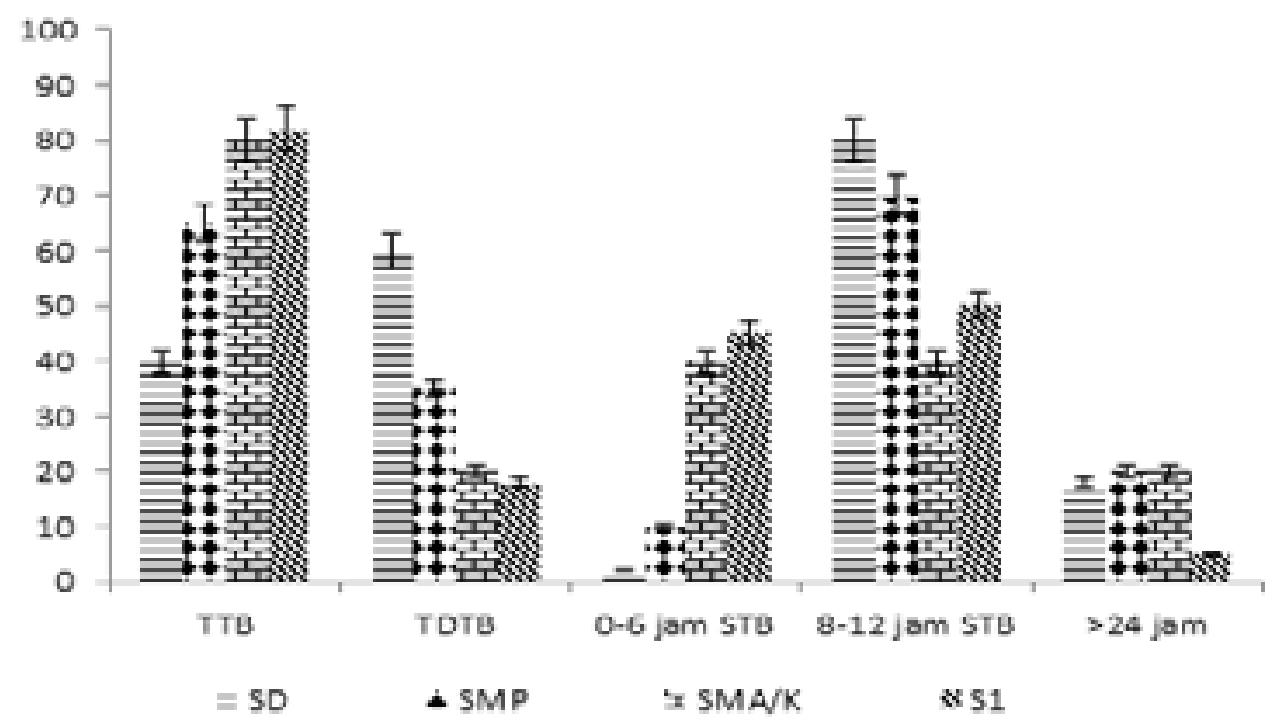

Keterangan: TTB (mengetahui tanda-tanda birahi), TDTB (tidak mengetahui tanda-tanda birahi), 0-6 jam STB (setelah tanda birahi), 8-12 jam (setelah tanda birahi)

Gambar 1. Tingkat Pendidikan Terhadap Pemahaman Estrus Pada Sapi

kualitas semen beku dan deteksi estrus yang tidak akurat. Menurut Schüller et al. (2017) bahwa tekanan panas dapat memicu stress dan secara signifikan dapat mengurangi intensitas tanda-tanda estrus eksternal, hal ini dapat ditandai dengan meningkatnya indek suhu dan kelembapan (THI). Estrus yang tidak menentu dapat menyebabkan deteksi yang tidak akurat, sehingga proses IB tidak dapat berjalan dengan baik, selain itu faktor waktu dalam pelaksanaan IB menjadi penting karena waktu IB yang telah melewati fase $4-5$ jam pada saat estrus dapat menurunkan CR. Annashru et al. (2017) menyatakan bahwa IB pada interval 0-4 jam memiliki CR lebih tinggi yaitu 70\% bila dibandingkan dengan IB pada interval 8-12 jam memiliki nilai CR 37,14\%. Menurut hasil wawancara dengan inseminator ternak sapi yang siap di IB paling mudah adalah jika sapi menunjukkan tanda-tanda vulva masih mengeluarkan cairan berupa lendir bening yang kental. Hal inilah yang jarang diketahui oleh para peternak sehingga kegagalan IB salah satu faktor disebabkan oleh ketidak tauan peternak. Gambar 1 menunjukkan rata-rata tingkat pendidikan dan pemahanan peternak dalam mengetahui status birahi sapi dan waktu yang tepat untuk di kawinkan.

Rata-rata tingkat pengetahuan peternak tentang estrus dan waktu sapi siap untuk dikawinkan cukup rendah dapat dilihat banwa waktu yang tepat untuk mengawinkan sapi antara 0-6 jam setelah estrus tidak mencapai $50 \%$, hal inilah yang menjadi salah satu penyebab banyaknya kegagalan IB pada tiga lokasi tersebut rata-rata hanya mencapai $67 \%$. Tingkat pendidikan peternak tidak menjamin dapat mengetahui estrus dengan baik pada tingkat pendidikan SD dan SMP dengan rata-rata lama beternaka antara 3-8 tahun. Selain itu jarak aseptor memberikan pengaruh terhadap keberhasilan IB, semakin jauh jarak akan berdampak terhadap peningkatan S/C. Peternak memberitahukan sapi birahi kepada inseminator pada sore hari dan akan dilaksanakan IB pada pagi hari selain itu jarak tempuh paling dekat adalah $15 \mathrm{~km}$ inilah salah satu penyebab fase strus telah berubah. Menurut Haryanto et al. (2015) bahwa jarak tempuh antara aseptor dengan inseminator dapat menyebabkan tingkat kegagalan IB menjadi lebih tinggi, hal ini dikarenakan kondisi sapi telah berada pada fase yang tidak ideal untuk terjadinya fertilisasi. 
Hasil penelitian menunjukkan bahwa umur sapi dara pertama kali dikawinkan ratarata adalah 24,5 bulan hasil ini lebih tinggi dari penelitian sebelumnya yang dilakukan oleh Desinawati dan Isnaeni (2010) yang menyatakan bahwa umur sapi betina pertama kali dikawinkan pada 19,77 bulan pada jenis sapi simental. Perbedaan ini dapat dipahami karena jenis dan suhu yang berbeda, namun penelitian ini sejalan dengan penelitian Haryanto et al. (2015) yang menyatakan bahwa jenis sapi lokal seperti sapi bali ratarata memeiliki waktu pertama kali dikawinkan adalah 20,15 bulan. Lama siklus birahi pada penelitian ini rata-rata 21,67 hari penelitian ini dalam kisaran normal sesuai dengan temuan Röttgen et al. (2018) bahwa lama siklus birahi normal berkisar antara 22.6 hari pada jenis sapi perah, sedangkan pada sapi lokal lama birahi mencapai 18-21 hari (Kune dan Solihati, 2007). Hasil penelitian menunjukkan bahwa lama bunting rata-rata adalah 278,33 anak jantan dan 274,33 anak betina. Nilai ini lebih rendah dari hasil penelitian yang dilakukan oleh Bahtiar et al. (2015) bahwa lama bunting rata-rata adalah 280 hari dengan perbedaan waktu 5 hari lebih lama pada jantan, dan menurut Neto et al. (2017) bahwa rata-rata kelahiran sapi adalah $270-282$ hari setelah di IB pada sapi Fries Hollands. Perbedaan ini dikarenakan jenis ternak yang diamati berbeda serta pengaruh lingkungan yang kuat. Merauke dengan suhu yang cukup panas dapat menyebabkan gangguan dalam proses kelahiran, karena proses regulasi metabolisme dalam tubuh yang tidak konstan sehingga dapat mempengaruhi tingkat stress sehingga memicu peningkatan hormon kortisol sebagai salah satu penyebabnya. Gilles et al. (2018) menyatakan bahwa stress yang ditimbulkan pada saat sebelum kelahiran dapat memicu peningkatan hormon kortisol saliva sirkadian.

Peternak sapi lokal di kawasan tiga distrik rata-rata mengawinkan sapi betinanya setelah beranak adalah 3 - 5 bulan, Namun hasil penelitian menunjukkan proses reproduksi pada sapi betina mulai dikawinkan kembali setelah beranak rata-rata 129 hari, hasil ini termasuk kedalam kisaran normal. Penelitian lain pada jenis ternak yang sama rata-rata betina mulai dikawinkam kembali setelah beranak adalah 127 hari (Bahtiar et al., 2015).

Tingkat kematian pedet berhubungan erat dengan kemampuan SDM dalam penanganan kebuntingan. Hasil penelitian menunjukkan bahwa pengalaman beternak memberikan pengaruh cukup besar didalam proses manajemen induk bunting dan prenatal. Rata-rata 8,3 atau setara dengan $18,04 \%$ dari total kematian pedet disebabkan oleh faktor eksternal yaitu manajemen pemeliharaan ternak yang kurang baik. Salah satu contoh adalah sapi bunting pada musim panas anatara bulan agustus - oktober mengkonsumsi nutrisi yang sangat rendah, hanya jerami padi kering yang memiliki kandungan jerami memmiliki kandungan lignin dan silika yang tinggi serta rendah energy, protein dan vitamin (Van Soest, 2006). Konsumsi air pada sapi bunting hasil penelitian menunjukkan pada musim panas hanya mengkonsumsi ratarata 5 liter air minum perhari sehingga BCS dapat mencapai 1 dan 2. Menurut Zimpel et al. (2018) bahwa kebutuhan air minimum pada sapi bunting mencapai 20 Liter per hari, dengan penambahan cation dan anion dalam pakan penggunaan air minum dapat meningkat sebanyak $20 \%$. Guna menghindari terjadinya hal serupa perlu adanya pelatihan dan pemahaman kepada peternak untuk memanfaatkan teknologi pakan seperti fermentasi jerami sehingga asupan nutrisi dari pakan dapat terpenuhi khususnya induk bunting dan lactasi. Proses fermentasi dapat menurunkan kandungan nilai lignin dan selulosa dan mampu meiningkatkan nilai nutrisi pada jerami tersebut, namun secara umum pemberian jerami padi sebagai pakan tunggal tidak memenuhi syarat sebagai pakan pada sapi (Sarnklong et al., 2010).

\section{KESIMPULAN}

Performa reproduksi pada sapi lokal di merauke dengan keadaan suhu tinggi memiliki 
status reproduksi umur pubertas, lama bunting, siklus birahi dalam keadaan normal, hal ini dapat diartikan bahwa sapi-sapi lokal di merauke telah tolerans. Namun nilai S/C pada sapi lokal yang di IB memiliki nilai $>1$ akan tetapi masih dalam ambang batas normal yaitu nilai S/C1-2. Kegagalan reproduksi atau kematian pedet terjadi akibat faktor eksternal yaitu SDM peternak yang perlu ditingkatkan.

\section{DAFTAR PUSTAKA}

Annashru, F., A. Ihsan, M., N. Yekti, A., P., dan A. Susilowati, T. 2017. Pengaruh perbedaan waktu inseminasi buatan terhadap keberhasilan kebuntingan Sapi Brahman Cross. Jurnal Ilmu-Ilmu Peternakan 27 (3): 17 - 23.

Bakhtiar, Yusmadi, dan Jamaliah. 2015. Study of Reproduction Performance Aceh Cattle as the Basis for Information the Germplasm Preservation of Local Livestock. Jurnal Ilmiah Peternakan 3 (2) : 29-33.

Desinawati, N dan Isnaeni, N. 2010. Penampilan reproduksi sapi peranakan simmental di kabupaten tulungagung jawa timur. J. Ternak Tropika Vol. 11, No.2:-41-47.

Dinas Peternakan dan Kesehatan Hewan. 2015. Laporan kinerja dinas peternakan dan kesehatan hewan kabupaten merauke.(ID) Indonesia.

Gilles, M., Otto, H., Isabell., Wolf, A.C., Scharnholz, and B. Peus, V. 2018. Maternal hypothalamus-pituitaryadrenal (HPA) system activity and stress during pregnancy: Effects on gestational age and infant's anthropometric measures at birth. Psychoneuroendocrinology. Vol 94 : 152-161.

Haryanto, D., Hartono, M dan S. Suharyanti. 2015. Beberapa faktor yang memengaruhi service per conception pada sapi bali di Kabupaten Pringsewu.
Jurnal Ilmiah Peternakan Terpadu Vol. 3(3): 145-150.

Ihsan, M. N dan S. Wahyuningsih. 2011. Penampilan reproduksi sapi potong di Kabupaten Bojonegoro. Jurnal Ternak Tropika. 12 (2):76-8.

Iskandar. 2007. Performan Reproduksi Sapi PO pada Dataran Rendah dan Dataran Tinggi di Provinsi Jambi. Jurnal Ilmiah Ilmu-Ilmu Peternakan. 15 (1)

Kune P dan N. Solihati. 2007 Tampilan Berahi dan Tingkat Kesuburan Sapi Bali Timor yang Diinseminasi. Jurnal Ilmu Ternak. 7 (1): $1-5$.

Neto,A.V., Galvão, K.N., Thatcher, W.W. and J.E.P. Santos. 2017. Association among gestation length and health, production, and reproduction in Holstein cows and implications for their offspring. Journal of Dairy Science. Vol 100 (4):31663181.

Novita, C.I., Sari, E.M. dan E. Rahma. 2018. Karakterisasi Penampilan Reproduksi Sapi Aceh Betina Sebagai Sumber Daya Genetik Ternak Lokal di Kota Subulussalam. Agripet. 18 (1) : 36 -40.

Röttgen, V., Becker, F., Tuchscherer, A., Wrenzycki, C., Düpjan., Schön, P.C. and B. Puppe. 2018. Vocalization as an indicator of estrus climax in Holstein heifers during natural estrus and superovulation. Journal of Dairy Science Vol. 101 No. 3.

Sarnklong, C., Cone, J., W. Pellikaan., W. and W. H Hendriks. 2010. Utilization of Rice Straw and Different Treatments to Improve Its Feed Value for Ruminants: A Review. Asian-Aust. J. Anim. Sci.23 (5) : $680-692$.

Schüller, L.K., Michaelis, I. and W. Heuwieser. 2017. Impact of heat stress on estrus expression and follicle size in estrus under field conditions in dairy cows. Theriogenology. 93: 691

Sumiyoshi, T., Tanaka, T. and H. Kamomae. 2014. Relationship between the 
appearences and changes of estrous signs and estradiol-17 $\beta$ peak, leutinizing hormone surge and ovulation during the periovulatory period in lactating dairy cows. J.Dairy Sci. 95, 7115-7127.

Toelihere, M. R. 1987. Fisiologi Reproduksi pada Ternak. Penerbit Angkasa. Bandung.

Umiyasih, U dan Y. N. Anggraeny. 2007. Petunjuk Teknis Ransum Seimbang, Strategi Pakan Pada Sapi Potong, Laporan Penelitian, Pusat Penelitian dan Pengembangan Peternakan, Badan Penelitian Dan Pengembangan
Pertanian, Depertemen Pertanian, Jakarta.

Van Soest, P. 2006. Rice Straw, the Role of Silica and Treatments to Improve Quality. Animal Feed Science and Technology, 130 (14):137-171.

Zimpel, R., Poindexter, R.B., Neto, A. V., Block, E., Nelson, C.D., Staples, C.R., Thatcher, W. W. and J.E.P. Santos. 2018. Effect of dietary cation-anion difference on acid-base status and dry matter intake in dry pregnant cows. J. Dairy Sci. 101:1-15. 